\title{
KOMUNIKASI ANTARPRIBADI: Suatu Kajian dalam Perspektif Komunikasi Islam
}

\author{
Azhar \\ Institut Agama Islam Negeri Langsa \\ Email: Razaqna70@yahoo.com
}

\begin{abstract}
Abstrak
Tujuan penulisan ini membahas tentang komunikan antarpribadi dalam perspektif komunikasi Islam, sebagaimana yang tercantun dalam surat al-Nabl ayat 125, yaitu dengan cara hikemah, mau'idzat hasanah, mujädalah billati hiya ahsan. Dari beberapa pendapat abli diketabui bahwa komunikasi antarpribadi biasanya dilakukan secara tatap muka (face to face) sehingga terjadilah kontak pribadi (personal contact). Dengan demikian, hasil umpan balik berlangsung seketika, akhirnya komunikator dapat mengetahui apakah komunikasinya ditanggapi positif atau negatif oleb komunikan. Hal ini dapat dilihat dari mimik atau ekspresi wajah. Jika tanggapan komunikan itu negatif, maka dapat diubah gaya komunikasi tersebut.

Ditinjau dari teori-teori komunikasi antarpribadi dalam perspektif komunikasi Islam, lebih dititik beratkan kepada proses penyampaian pesan atau informasi dari komunikator kepada komunikan, dengan menggunakan kaedah dan prinsip komunikasi yang berdasarkan kepada Alquran dan Hadis. Proses penyampaian pesan kepada audien secara langsung atau melalui media menjunjung kebenaran yang diajarkan oleh agama. Dalam proses ini umpan balik (feedback) dalam komunikasi Islam bukan kepada komunikatornya, tetapi kepada mad'ü, berbeda dengan komunikasi umum yang lebih mengutamakan kepentingan politik dan material.

Komunikasi antarpribadi dalam persfektif Islam disebut dengan dakwah fardiyah. Dalam penyampaiannya diperlukan pengetahuan dalam komunikasi dan kebijaksanaan seorang dai. Seorang dai yang bijaksana adalab orang yang dapat mempelajari realitas, situasi masyarakat, dan kepercayaan mereka serta menempatkean mereka pada tempatnya masing-masing. Dai mengajak mereka berdasarkan kemampuan akal, pemahaman, tabiat, tingkatan keilmuan dan status sosial mereka.
\end{abstract}

Kata Kunci: Interpersonal Communication, Komunikasi Islam, Prinsip Umpan Balik

\section{A. Pendahuluan}

Komunikasi antarpribadi (interpersonal communication) dalam perspektif Islam disebut dengan dakwah fardiyah. Hal ini dapat dilakukan di berbagai tempat dan beberapa kali dalam satu hari (Masyhur, 2001: 76). Dakwah fardiyah secara umum didefinisikan sebagai usaha dai secara individu untuk mengenalkan islam dan iman kepada siapa saja, juga mencegahnya dari perbuatan yang dilarang Allah dengan jalan mendekatinya, mengajarinya, serta membimbingnya, sehingga terjadi proses amar makruf dan nahi munkar (Syathibi, 2003: 12).

Dakwah fardiyah menurut Mahmud (2004: 1) sebagai antonim dari dakwah jama'iyah atau 'ammah yaitu ajakan atau seruan ke jalan Allah yang dilakukan oleh seorang dai (penyeru) kepada orang lain secara perorangan 
dengan tujuan memindahkan al-mad'ü pada keadaan yang lebih baik dan diridai Allah Swt.

Perubahan atau perpindahan tersebut adakalanya dari kekafiran kepada keimanan, dari kesesatan dan kemaksiatan kepada petunjuk dan ketaatan. Dari sikap ananiyah (individualism) dan (chauvinism) kepada sikap mencintai orang lain. Dalam sejarah perjalanan dakwah Rasulullah Saw, pertama sekali beliau melakukan dakwah fardiyah kepada orang yang paling dekat, yaitu bertemu langsung (face to face). Maka orang yang beliau seru tentang Islam langsung menerima Islam dengan terbuka, karena mereka tidak menyangsikan lagi tentang keagungan dan kejujuran pengabaran yang beliau sampaikan. Orang-orang yang pertama sekali menerima Islam disebut dengan al-säbiqūn al-awwalūn (yang terdahulu dan yang pertama-tama masuk Islam). Mereka adalah istri beliau, umm al-mu'minin Khadījah binti Khuwailid, pembantu beliau Zaid bin Harītsah bin Syahbil al-Kalby, 'Alī bin Abī Thālib, dan sahabat beliau Abū Bakr al-Shiddīq.

Dari Abū Bakr yang sudah masuk Islam, maka berbondong-bondong sahabat lainnya yang ikut masuk Islam seperti, 'Utsmān bin 'Affān, al-Zubair bin al-'Awwām, 'Abd al-Rahman bin 'Auf, Sa'ad bin Abī Waqqash dan Thalhah bin 'Ubaidillāh, dikarenakan dengan figur Abū Bakr yang lemah lembut, pengasih dan ramah memiliki akhlak yang mulia dan terkenal. Dakwah ini dilakukan Rasulullah dan sahabat dengan cara sembunyi-sembunyi selama tiga tahun (AlMubarakfuri, 2011: 72).

Rasulullah Saw. melakukan dakwah secara terang-terangan setelah turun ayat yang berbunyi:

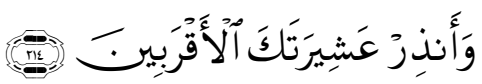

Dan berilah peringatan kepada kerabat-kerabatmu yang terdekat. (QS. al-Syu'arā'/26: 214)

Langkah dakwah Rasulullah Saw. selanjutnya dilakukan secara terangterangan yaitu dengan mengundang Bani Hasyim untuk dapat menerima Islam. Dalam dakwah ini Rasulullah Saw. menggunakan komunikasi interpersonal secara persuasif. Firman Allah Swt.:

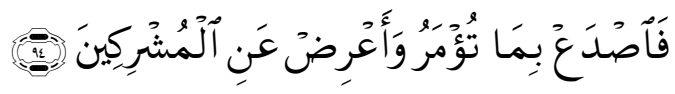

Maka sampaikanlah olebmu secara terang-terangan segala apa yang diperintabkan (kepadamu) dan berpalinglah dari orang-orang yang musyrik. (QS. al-Hijr/15: 94)

Dalil yang cukup jelas diterangkan berhubungan dengan komunikasi antarpribadi sebagaimana dengan firman Allah Swt:

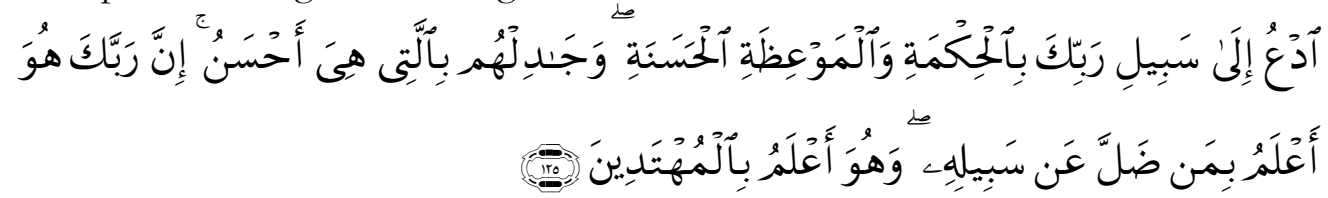

Serulah (manusia) kepada jalan Tuban-mu dengan bikmah dan pelajaran yang baik dan bantablah mereka dengan cara yang baik. Sesunggubnya Tuhanmu Dialah yang lebih 
mengetahui tentang siapa yang tersesat dari jalan-Nya dan Dialah yang lebih mengetahui orang-orang yang mendapat petunjuk. (QS. al-Nahl/16: 125)

\section{B. Pengertian Komunikasi Antarpribadi (Interpersonal Communication)}

Komunikasi antarpribadi (interpersonal communication) didefenisikan oleh Joseph A. Devito dalam bukunya "The Interpersonal Communication Book". "The process of sending and receiving messages between two persons, or among a small group of persons, with some effect and some immediate feedback." (Devito, 1989: 4) "Proses pengiriman dan penerimaan pesan-pesan antara dua orang atau di antara sekelompok kecil orang-orang, dengan beberapa efek dan beberapa umpan balik seketika".

Komunikasi antarpribadi dapat berlangsung antara dua orang yang memang sedang berdua-duaan seperti suami istri yang sedang bercakap-cakap, atau antara dua orang dalam suatu pertemuan, misalnya antara penyaji makalah dengan salah seorang peserta suatu seminar (Effendy, 2003: 60).

Komunikasi antarpribadi adalah sangat penting dikarenakan komunikasi antarpribadi melibatkan personalnya antara dua orang atau lebih secara langsung yaitu dengan tatap muka. seperti yang dikatakan oleh R. Wayne Pace dalam Haffied Cangara bahwa "Interpersonal communication is communication involving two or more people in a face setting" (Cangara, 2008: 32). Selain itu Onong Uchjana Effendi mengemukakan komunikasi antarpribadi dianggap paling ampuh dalam upaya mengubah sikap, kepercayaan, opini, dan perilaku komunikan (Effendy, 2003: $62)$.

Dari beberapa pendapat di atas dapat diketahui bahwa komunikasi antarpribadi berlangsung secara tatap muka (face to face) maka terjadilah kontak pribadi (personal contact), sehingga hasil umpan balik berlangsung seketika, sehingga komunikator dapat mengetahui apakah komunikasinya ditanggapi positif atau negatif oleh komunikan dan hasil ini dapat dilihat dari mimik atau ekspresi wajah, jika tanggapan komunikan itu negatif maka dapat diubah gaya komunikasi tersebut. Namun saat ini dengan perkembangan teknologi yang semakin maju memberi kemudahan dalam melakukan komunikasi antarpribadi, terkadang bertatap muka langsung (face to face) itu tidak harus bertemu secara langsung, karena dengan adanya media komunikasi sehingga dikatakan bahwa dunia itu dalam genggaman itu terjadi. Media komunikasi yang digunakan seperti telephone, handphone, teleconference, internet, dan sebagainya. Bahkan untuk handphone saat sekarang ini yang sudah mempunyai fasilitas $4 \mathrm{G}$, sudah dapat bertatap muka di depan layar secara langsung, begitu juga dengan internet dan teleconference.

Pendapat lain mengatakan bahwa komunikasi antarpribadi merupakan proses pengiriman dan penerimaan pesan di antara dua orang atau di antara sekelompok kecil orang, dengan berbagai efek dan umpan balik (feed back) (Widjaya, 2000: 122).

Pendapat lain seperti Mulyana mengatakan, pemahaman tentang komunikasi bertatap muka langsung harus diawali dengan pembentukan konsep diri. Bahwa konsep diri yaitu pandangan kita mengenai siapa diri kita, dan itu dapat diperoleh lewat informasi yang diberikan orang lain kepada kita. Konsep 
diri paling dini pada umumnya dipengaruhi oleh keluarga dan orang-orang yang dekat lainnya di sekitar kita. Mereka itulah disebut dengan significant other. Orang tua kita atau siapapun yang pertama kali memelihara kita, mereka itulah yang pertama kali mengetahui bagaimana kita. Oleh karena itu, Mulyana mengatakan bahwasanya manusia itu tidak pernah berkomunikasi dengan manusia lainnya mereka tidak sadar bagaimana diri mereka sebenarnya dan kesadaran itu didapatkan dari suatu proses komunikasi yang disebut komunikasi antarpribadi (Widjaya, 2001: 7-8).

Sedangkan menurut Arni Muhammad mengatakan bahwa Komunikasi antarpribadi adalah proses pertukaran informasi di antara seseorang dengan paling kurang seorang lainnya atau biasanya di antara dua orang yang dapat langsung diketahui balikannya. Dengan bertambahnya orang yang terlibat dalam komunikasi, menjadi bertambahlah persepsi orang dalam kejadian komunikasi sehingga bertambahlah komplekslah komunikasi tersebut. Komunikasi antarpribadi adalah membentuk hubungan dengan orang lain (Muhammad, 2002: 159).

Dari beberapa definisi di atas dapat diambil kesimpulan bahwa komunikasi antarpribadi adalah komunikasi antar-perorangan dan bersifat pribadi baik yang terjadi secara langsung (tanpa podium) ataupun tidak langsung (melalui podium). Contohnya kegiatan percakapan tatap muka, percakapan melalui telephone, HP, Internet, teleconference, surat menyurat pribadi. Fokus pengamatannya adalah bentuk-bentuk dan sifat-sifat hubungan (relationship), percakapan, interaksi dan karakteristik komunikator. Sedangkan dengan melalui podium yaitu dengan dakwah fardiyah dengan misi pesan-pesan dakwah kepada mad' $\bar{u}$ untuk menyeru perbuatan yang makruf dan mencegah perbuatan munkar.

Dari beberapa pendapat di atas, Widjaya menyimpulkan bahwa tujuan komunikasi antarpribadi mempunyai tujuan sebagai berikut:

1. Mengenal diri sendiri dan orang lain.

2. Mengetahui dunia luar.

3. Menciptakan dan memelihara hubungan.

4. Mengubah sikap dan perilaku.

5. Membantu orang lain (Widjaya, 2000: 123).

\section{Tinjauan Teori-Teori Komunikasi Antarpribadi}

Dari tinjauan teori-teori komunikasi antarpribadi (interpersonal communication) di atas Sendjaja dalam bukunya yang berjudul Teori Komunikasi menyatakan bahwa, Secara umum komunikasi antarpribadi dapat diartikan sebagai suatu proses pertukaran makna antara orang-orang yang saling berkomunikasi. Pengertian proses mengacu pada perubahan dan tindakan (action) yang berlangsung terus-menerus. Komunikasi antarpribadi juga merupakan suatu pertukaran, yaitu tindakan menyampaikan dan menerima pesan secara timbal balik. Sedangkan makna, yaitu sesuatu yang dipertukarkan dalam proses tersebut, adalah kesamaan pemahaman di antara orang-orang yang berkomunikasi terhadap pesan-pesan yang digunakan dalam proses komunikasi (Sendjaya, 1994: 41). 
Dari definisi komunikasi antarpribadi (interpersonal communication) yang telah diuraikan di atas komunikasi antarpribadi merupakan suatu proses yang sangat unik. Artinya kegiatan yang terjadi dalam komunikasi antarpribadi tidak seperti kegiatan lainnya, seperti menyelesaikan soal matematika, mengikuti perlombaan, menulis suatu artikel, atau merancang kampanye periklanan. Komunikasi antarpribadi melibatkan paling sedikit 2 orang yang mempunyai sifat, pendapat, pikiran dan prilaku yang khas dan berbeda-beda. Selain itu, komunikasi antarpribadi melibatkan di antara pelaku dalam komunikasi. Dengan kata lain para pelaku komunikasi saling bertukar informasi, pikiran, gagasan, dan sebagainya. Dengan adanya pertukaran ini komunikasi disebut sebagai komunikasi transaksional.

Bila kita mengatakan bahwa komunikasi antarpribadi adalah proses transaksional, berarti: Pertama, komunikasi antarpribadi merupakan proses. Kedua, komponen-komponennya saling tergantung (interpendensi) pelaku komunikasi bertindak sekaligus bereaksi.

Dari beberapa pengertian yang telah disebutkan di atas oleh Judi C. Pearson (1983) menyebutkan bahwa ada 6 (enam) karakteristik yang menentukan kegiatan dapat disebut sebagai komunikasi antarpribadi yaitu:

1. Komunikasi pribadi dimulai dari diri sendiri (self). Maksudnya, berbagai persepsi komunikasi yang menyangkut pengamatan dan pemahaman berangkat dari dalam diri kita, artinya dibatasi oleh siapa diri kita dan bagaimana pengalaman kita.

2. Komunikasi antarpribadi bersifat transaksional. Anggapan ini mengacu pada tindakan pihak-pihak yang berkomunikasi secara serempak menyampaikan dan menerima pesan.

3. Komunikasi antarpribadi mencakup aspek-aspek isi pesan dan hubungan antarpribadi. Maksudnya komunikasi antarpribadi tidak hanya berkenaan dengan isi pesan yang dipertukarkan, tetapi juga melibatkan siapa patner komunikasi kita dan bagaimana hubungan kita dengan partner tersebut.

4. Komunikasi antarpribadi mensyaratkan adanya kedekatan fisik antara pihak-pihak yang berkomunikasi.

5. Komunikasi antarpribadi melibatkan pihak-pihak yang saling tergantung satu dengan lainnya (interdependen) dalam proses komunikasi.

6. Komunikasi antarpribadi tidak dapat diubah maupun diulang. Jika kita salah mengucapkan sesuatu kepada partner komunikasi kita, mungkin kita dapat meminta maaf dan diberi maaf, tetapi itu tidak berarti menghapus apa yang pernah kita ucapkan. Demikian pula kita tidak dapat mengulang suatu pernyataan dengan harapan untuk mendapatkan hasil yang sama, karena dalam proses komunikasi antar manusia, hal ini akan sangat tergantung dari respons partner komunikasi kita (Sendjaya, 1994: 41). 


\section{Kelebihan dan Kekurangan Komunikasi Antarpribadi dengan Komunikasi Lainnya}

1. Tatap Muka Langsung

a. Kelebihannya:

- Langsung menerima feedback dari komunikannya saat proses interaksi berlangsung.

- Isi atau kedalaman sebuah pesan dapat tersampaikan dengan jelas dan juga dipertegas dengan komunikasi non-verbal dari lawan bicara yang dapat dilihat langsung.

- Komunikasi tatap muka dapat dengan mudah membujuk lawan bicaranya karena adanya pengaruh komunikasi lain dan pengaruh lingkungannya.

b. Kekurangannya:

- Komunikasi antarpribadi mensyaratkan adanya kedekatan fisik antara pihak-pihak yang berkomunikasi.

- Komunikator dan komunikan harus mengorbankan waktu yang dimiliki untuk berkomunikasi.

- Jangkauannya yang sempit, maksudnya ialah individu-individu yang terlibat terbatas antara dua orang atau beberapa orang saja.

- Komunikasi antarpribadi tidak dapat diubah maupun diulang. Jika kita salah mengucapkan sesuatu kepada partner komunikasi kita, mungkin kita dapat meminta maaf dan diberi maaf, tetapi itu tidak berarti menghapus apa yang pernah kita ucapkan. Demikian pula kita tidak dapat mengulang suatu pernyataan dengan harapan untuk mendapatkan hasil yang sama, karena dalam proses komunikasi antar manusia, hal ini akan sangat tergantung dari respons partner komunikasi kita.

- Komunikasi antarpribadi melibatkan pihak-pihak yang saling tergantung satu dengan lainnya (interdependen) dalam proses komunikasi.

- Komunikasi antarpribadi bersifat transaksional. Anggapan ini mengacu pada tindakan pihak-pihak yang berkomunikasi secara serempak menyampaikan dan menerima pesan.

\section{Melalui Media}

a. Kelebihannya:

- Efektif karena menghemat waktu dan bisa dilakukan dimana saja, dan kapan saja kita inginkan.

b. Kelemahannya:

- Kelemahannya dari segi biaya yang harus ditanggung ketika berkomunikasi lewat internet, teleconference, Hp, telephone dan sebagainya.

- Tidak dapat digunakan untuk mempersuasi seseorang karena komunikasi yang dilakukan bersifat virtual.

- Adanya faktor kecepatan dan keluasan jaringan dalam pengaksesan informasi sehingga tidak terbatas untuk kita melakukan komunikasi dengan beberapa orang atau banyak orang. 


\section{E. Komunikasi Antarpribadi dalam Perspektif Komunikasi Islam}

Dari beberapa teori komunikasi antarpribadi (interpersonal communication) oleh beberapa ahli komunikasi, serta dalam Alquran dan Hadis untuk mendukung komunikasi yang baik, ini menjadikan dasar pondasi untuk membangun komunikasi antarpribadi itu sendiri.

Dalam perspektif komunikasi Islam menurut Husain dan lain-lain, dalam Syukur Kholil, lebih dititik beratkan kepada proses penyampaian pesan atau informasi dari komunikator kepada komunikan dengan menggunakan kaedah dan prinsip komunikasi yang berdasarkan kepada Alquran dan Hadis (Kholil, 2007: 2). Dengan demikian, proses penyampaian pesan baik secara langsung atau melalui media lebih menjunjung kepada kebenaran yang diajarkan oleh agama.

Biasanya prinsip umpan balik (feed back) pada komunikasi umum adalah komunikator, komunikasi antarpribadi dalam persfektif umum lebih mengutamakan kepentingan politik dan material, namum dalam komunikasi Islam umpan balik (feed back) adalah kepada komunikannya (mad'ü). Dalam hal ini, komunikator atau dai menyadari sepenuhnya peran yang diemban untuk menyampaikan dakwah kepada mad'ú adalah untuk kebaikan umat, umpan baliknya (feed back) yaitu demi mendapatkan keridhoan dari Allah Swt.

Komunikasi antarpribadi dalam perspektif Islam disebut dengan dakwah fardiyah yang dilakukan oleh komukator Islam kepada mad'ú. dalam proses ini diperlukan pengetahuan dalam komunikasi dan kebijaksanaa oleh seorang dai. Seorang dai yang bijaksana adalah orang yang dapat mempelajari realitas, situasi masyarakat, dan kepercayaan mereka serta menempatkan mereka pada tempatnya masing-masing. Kemudian ia mengajak mereka berdasarkan kemampuan akal, pemahaman, tabiat, tingkatan keilmuan dan status sosial mereka (Al-Qahthani, 2006: 97). Sebagaimana hadis Rasulullah Saw.:

Dari 'Alì ibn Abi Thälib mengatakan, bicaralah dengan orang sesuai dengan apa yang mereka ketabui. Apakah kalian suka Allab dan Rasul-Nya didustakan. (HR. Muslim).

Selain itu materi dakwah disesuaikan dengan kondisi masyarakat. Terutama pada masyarakat pedesaan yang terdiri dari orang-orang yang pendidikannya masih rendah bahkan buta huruf. Mereka belum bisa berfikir secara kritis dan mendalam, belum dapat mengangkap materi dakwah dengan cepat dan pengertian yang tinggi. Di samping itu mereka masih memegang teguh tradisi dan adat istiadat mereka. Mungkin ada sebagian dari mereka ada yang bersedia menerima setiap yang baru, tetapi mungkin ada pula sebagian yang secara gigih mempertahankan tradisi-tradisi mereka yang sudah berakar. Untuk masyarakat perkotaan sebagai objek dakwah, para komunikator atau dai, ini merupakan tantangan yang tersendiri karena tentu saja masyarakat perkotaan dengan berbagai individu dari daerah tertentu dengan bermacam tingkat kecerdasannya dan tradisi berbeda serta tabiatnya tentu saja harus memilih materi dan metode yang baik supaya dapat diterima. Begitu juga komunikasi antarpribadi dengan golongan cendikiawan yang tingkat pendidikan yang sudah tinggi, dalam melakukan dakwah ini haruslah menggunakan bahasa dengan uraian yang teratur, logis dan sesuai dengan penalaran, sehingga dakwahnya 
dapat diterima. Walau terkadang para cerdik cendikiawan tersebut ada yang menolaknya.

Sebagaimana dengan hadis Rasululllah Saw. yaitu:

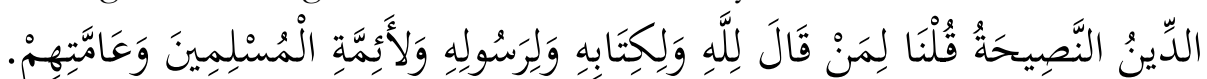

Agama adalah nasihat, kami bertanya, untuk, siapa wahai Rasulullah? Beliau menjawab: untuke Allah, kitab-Nya, Rasul-Nya, pemimpin-pemimpin Islam dan orang-orang muslim awam." (HR. Muslim).

Mempelajari keadaan dan situasi sangatlah penting, sebab dai dituntut untuk mengenali keadaan masyarakat yang didakwahi baik aqidah, psikologis, sosial dan ekonominya, begitu juga ia dituntut untuk mengetahui dengan baik letak pusat kejahatan dan kesesatan mereka. Dai juga harus mengenal bahasa, dialek, adat kebiasaan masyarakatnya. Seorang dai hanya akan sukses di dalam dakwahnya, disukai penyampaiannya dan lurus perkataan dan perbuatannya.

Di dalam Alquran telah dijelaskan bagaimana seharusnya yang dilakukan oleh komunikator dalam hal ini adalah para dai dalam melakukan dakwahnya. Sebagaimana dengan firman Allah Swt:

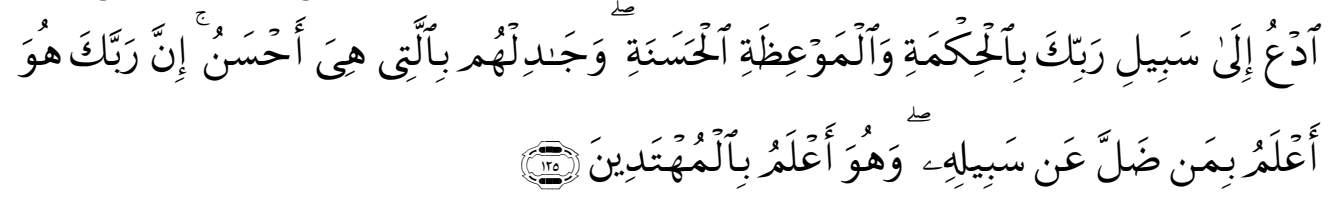

Serulah (manusia) kepada jalan Tuban-mu dengan bikemah dan pelajaran yang baik dan bantablah mereka dengan cara yang baik. Sesunggubnya Tuhanmu Dia-lah yang lebih mengetahui tentang siapa yang tersesat dari jalan-Nya dan Dia-lah yang lebib mengetabui orang-orang yang mendapat petunjuk. (QS. al-Nahl/16: 125).

Syekh Muhammad 'Abduh menyimpulkan ayat di atas bahwa dalam garis besarnya umat yang dihadapi oleh pembawa dakwah dapat dibagi atas tiga golongan, yang masing-masing harus dihadapi dengan cara yang berbeda-beda yaitu:

1. Golongan cerdik-cendikiawan yang cinta kebenaran dan dapat berpikir secara kritis dan mempunyai daya tangkap yang cepat. Mereka ini harus dipanggil dengan hikmat, yakni dengan alasan-alasan, dalil-dalil dan hujjahhujjah yang dapat diterima oleh kekuatan akal mereka.

2. Golongan awam, yaitu orang umum yang belum dapat berpikir secara kritis dan mendalam, belum dapat menangkap pengerian-pengertian yang tinggi. Oleh karena itu sebaiknya dengan cara anjuran dan didikan yang baik dan dengan jalan yang mudah dipahami.

3. Golongan yang tingkat kecerdasannya di antara dua golongan tersebut di atas, mereka ini belum dapat dipanggil dengan hikmat, akan tetapi tidak sesuai juga kalau dipanggil seperti golongan awam. Mereka suka membahas sesuatu tetapi hanya dengan batas-batas tertentu dan tidak mendalam benar (Masy'ari, 1993: 73). 
Sedangkan Munir dalam bukunya Metode Dakwah menyimpulkan ayat alNahl ayat 125 di atas sebagai berikut:

\section{Dengan Cara Hikmah}

Yaitu kemampuan dari dai dalam menjelaskan tentang Islam serta realitas yang ada dengan argumentasi logis dan bahasa yang komunikatif sesuai dengan tingkat intelektual dan pendidikan, psikologis maupun sosial. Maksudnya di sini, dai tidak hanya sekedar menyampaikan ajaran agama tanpa mengamalkannya. Seharusnya dai tersebut yang pertama yang mengamalkan apa yang diucapkannya. Kemudian direalisasikan kepada masyarakat atau mad $\overline{\mathcal{u}}$.

\section{Dengan Cara Mau'izhah Hasanah}

Mau'izhab Hasanah dapat diartikan sebagai ungkapan yang yang mengandung unsur bimbingan, pendidikan, pengarahan, kisah-kisah, berita gembira, peringatan, pesan-pesan positif yang bisa dijadikan pedoman dalam kehidupan agar mendapatkan keselamatan dunia dan akhirat.

\section{Dengan Cara Mujädalab Billatī Hiya Absan}

Mujädalah billati hiya absan maksudnya berbantah-bantah dengan cara yang baik dengan perkataaan yang lemah lembut tidak dengan ucapan yang kasar atau mempergunakan sesuatu perkataan yang menyakitkan orang lain. Dengan bertukar pendapat yang dilakukan oleh kedua belah pihak secara sinergis yang tidak melahirkan permusuhan dengan tujuan agar lawan menerima pendapat yang diajukan dengan memberikan argumentasi dan bukti yang kuat. Antara satu dengan lainnya saling menghargai dan mengormati pendapat keduanya berpegang kepada kebenaran, mengakui kebenaran pihak lain dan ikhlas menerima hukuman kebenaran tersebut (Munir, 2009: 8-14). Hal ini sesuai dengan firman Allah Swt.:

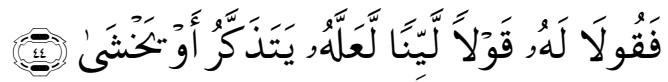

Maka berbicaralah kamu berdua kepadanya dengan kata-kata yang lemah lembut, Mudahmudahan ia ingat atau takut. (QS. Thaha/20: 44).

Adapun syarat-syarat seorang komunikator (dai) menurut perspektif Islam yaitu:

1. Qaulan sadidan adalah pembicaraan yang benar dan jujur dan tidak bohong.

2. Qaulan balighan yaitu berbicara jelas maknanya fasih, terang dapat dimengerti oleh komunikan (komunikasi efektif).

3. Qaulan masyhäran, yaitu perkataan yang pantas, ini bertujuan agar komunikasi tidak gagal, jika pembicaraan dan kata-kata yang dikemukakan pantas atau layak didengar oleh khalayak.

4. Qaulan layyinan, yaitu berbicara dilakukan dengan lemah lembut atau dilakukan dengan teknik persuasif (bujukan) karena Islam tidak ada kata paksaan atau memaksakan keinginan kepada orang lain. 
5. Qaulan kariman, yaitu perkataan yang mulia, dalam hal ini komunikator tidak menggunakan kata-kata kasar, seperti menghardik atau mencaci (Masyur, 2001: 79).

Di samping materi dakwah seorang dai dituntut untuk dapat menyesuaikan diri yakni membina silaturahmi dan persaudaraan sehigga kedekatan dengan mad' $\bar{u}$ akan terjaga dengan baik sehingga dapat membawa mad'u kepada keimanan dan ketaqwaan kepada Allah Swt, hal ini sesuai dengan firman-Nya:



Siapakah yang lebih baik, perkataannya daripada orang yang menyeru kepada Allah, mengerjakan amal yang shaleh dan berkata: "Sesunggubny a aku termasuk orang-orang yang berserah diri?" Dan tidaklah sama kebaikan dan kejahatan. Tolaklah (kejahatan itu) dengan cara yang lebib baik, maka tiba-tiba orang yang antaramu dan antara dia ada permusuban seolah-olah telah menjadi teman yang sangat setia. Sifat-sifat yang baik itu tidak dianugerabkan melainkan kepada orang-orang yang sabar dan tidak dianugerabkan melainkan kepada orang-orang yang mempunyai keberuntungan yang besar. Dan jika syaitan mengganggumu dengan suatu gangguan, maka mohonlah perlindungan kepada Allah. Sesunggubnya Dia-lab Yang Maha Mendengar lagi Maha Mengetabui. (QS. AlFushshilāt/41: 33-36).

Dari ayat-ayat di atas dapat diperoleh suatu pengertian bahwa juru dakwah dalam melakukan dakwah fardiyah (komunikasi antarpribadi) harus memiliki sifat-sifat khusus dan sikap hidup yang sesuai dengan tugasnya. Maka dapat dikatakan bahwa ayat-ayat ini merupakan dustur berdakwah secara umum dan dakwah fardiyah dalam proses komunikasi antarpribadi sendiri, karena di dalamnya memeuat asas dan rukun dakwah yang dapat dijelaskan sebagai berikut:

a. Seorang dai harus melakukan amal saleh, artinya ia harus melaksanakan seluruh kewajiban dan menjauhi dosa-dosa besar, selalu mendekatkan diri kepada Allah dengan melakukan amalan näfilab (sunah) dan menjauhi perbuatan-perbuatan yang hina dan dosa-dosa kecil.

b. Seorang dai harus menyatakan secara terus terang bahwa dia seorang muslim. Hal itu harus dinyatakan dengan perkataan, perbuatan, dan kesiapsiagaannya melakukan amar makruf dan nahi munkar serta, berjihad di jalan Allah, sehingga ia akan keluar dari lingkaran ria menuju keikhlasan dalam setiap ucapan dan perbuatannya. 
c. Seorang dai haru mengetahui dengan jelas perbedaan sikap lembut dalam bergaul dengan penerima dakwah, menolong, memaafkan yang akan berdampak baik dalam proses dakwah.

d. Seorang dai harus bersikap sabar, penyantun bergaul dengan penerima dakwah dengan baik, dan tabah terhadap kejelekan dan kekurangan yang dilakukan penerima dakwah.

e. Seorang dai harus berusaha berhati-hati terhadap godaan setan, dan harus meminta perlindungan Allah Swt.

f. Seorang dai harus mempunyai keyakinan yang kuat bahwa Allah Swt. selalu mendengar apa yang ia katakan dan melihat apa yang ia kerjakan (Mahmud, 1992: 31-32)

Dari ayat-ayat dan beberapa pendapat di atas dapat disimpulkan bahwa dalam proses komunikasi antarpribadi ada beberapa hal yang perlu diperhatikan dalam dalam melakukan kegiatan aktifitas dakwah harus mempunyai prinsip dalam berkomunikasi sebagaimana pendapat Syukur Kholil yaitu:

1. Memulai pembicaraan dengan salam

2. Berbicara dengan lemah lembut

3. Menggunakan perkataan yang baik

4. Menyebutkan hal-hal yang baik tentang komunikan

5. Menggunakan hikmah dan nesehat yang baik

6. Menyesuaikan bahasa dan isi pembicaraan dengan keadaan komunikan

7. Berdiskusi dengan cara yang baik

8. Lebih dahulu mengatakan apa yang dikomunikasikan

9. Mempertimbangkan pandangan dan fikiran orang lain

10.Berdoa kepada Allah ketika melakukan kegiatan komunikasi yang berat (Kholil, 2007: 8-13).

\section{F. Kesimpulan}

Dari beberapa definisi tentang komunikasi antarpribadi di atas bahwa komunikasi antarpribadi adalah proses pengiriman dan penerimaan pesan-pesan antara dua orang atau di antara sekelompok kecil orang-orang, dengan beberapa efek dan beberapa umpan balik (feed back) yang dapat diketahui hasilnya pada saat itu juga menerima atau tidak komunikan tersebut. Sedangkan komunikasi antarpribadi dalam perspektif Islam disebut dengan komunikasi fardiyah. Secara umum, disebutkan sebagai usaha dai secara individu untuk mengenalkan Islam dan iman kepada siapa saja, juga mencegahnya dari perbuatan yang dilarang Allah dengan jalan mendekatinya, mengajarinya, serta membimbingnya, sehingga terjadi proses amar makruf dan nahi munkar.

Di dalam melakukan komunikasi interpersonal dalam Islam dalam penyampaian dibagi dengan tiga golongan yaitu:

1. Golongan cerdik-cendikiawan yang cinta kebenaran dan dapat berpikir secara kritis dan mempunyai daya tangkap yang cepat. Mereka ini harus dipanggil dengan hikmat, yakni dengan alasan-alasan, dalil-dalil dan hujahhujah yang dapat diterima oleh kekuatan akal mereka. 
2. Golongan awam, yaitu orang umum yang belum dapat berpikir secara kritis dan mendalam, belum dapat menangkap pengerian-pengertian yang tinggi. Oleh karena itu sebaiknya dengan cara anjuran dan didikan yang baik dan dengan jalan yang mudah dipahami.

3. Golongan yang tingkat kecerdasannya di antara dua golongan tersebut di atas, mereka ini belum dapat dipanggil dengan hikmat, akan tetapi tidak sesuai juga kalau dipanggil seperti golongan awam. Mereka suka membahas sesuatu tetapi hanya dengan batas-batas tertentu dan tidak mendalam benar. 


\section{DAFTAR KEPUSTAKAAN}

Bungin, Burhan. Sosiologi Komunikasi. Jakarta: Kencana Media Group, 2006.

Center, Syathibi. Strategi \& Kiat Dakwah Fardiyah. Jakarta: Al-I'tishom Cahaya Umat, 2003.

Effendy, Onong Uchjana. Ilmu Teori Dan Filsafat Komunikasi. Bandung: PT. Citra Aditya Bakti, 2003.

Kholil, Syukur. Komunikasi Islam. Bandung: Citapustaka Media, 2007.

Mahmud, Ali Abdul Halim. Dakwah Fardiyab'Metode Membentuk Pribadi Muslim. Jakarta: Gema Insani, 1992.

Masy 'ari, Anwar. Butir-Butir Probelmatika Dakwah Islam. Surabaya: PT Bina Ilmu, 1993.

Masyhur, Mustafa. 7 Tahapan Dakwah Fardiyah. Jakarta: Alti-Syom Cahaya Ummat, 2001.

Muhammad, Arni. Komunikasi Organisasi. Jakarta: Bumi Aksara, 2002.

Mulyana, Deddy. Ilmu Komunikasi: Suatu Pengantar. Bandung: Remaja Rosda Karya, 2001.

Munir. M, et al. Metode Dakwah. Jakarta: Kencana, 2009.

al-Qahthani, Sa’id. Menjadi Dai Yang Sukses. Jakarta: Qisthi Press, 2006.

Sendjaya, S. Djuarsa. Teori Komunikasi. Jakarta: Universitas Terbuka, 1994.

Shafiyyurrahman, Al-Mubarakfuri. Sirah Nabawiyah. Jakarta: Pustaka Alkautsar, 2011.

Suprayitno, A. Komunikasi Antar Pribadi Tinjauan Psikologis. Yogyakarta: Kanisius, 1997.

Widjaya, H. AW. Ilmu Komunikasi Pengantar Studi. Jakarta: Rineka Cipta, 2000. 